https://helda.helsinki.fi

Phenomenology and Crisis : Tradition and Responsibility in Husserl and Heidegger

\title{
Miettinen, Timo
}

2009

Miettinen , T 2009 , ' Phenomenology and Crisis : Tradition and Responsibility in Husserl

and Heidegger ' , Philosophy Today , vol. 2009 , no. 34 , pp. 108-115 . https://doi.org/10.5840/philtoday200953Supp

http://hdl.handle.net/10138/18450

https://doi.org/10.5840/philtoday200953Supplement33

publishedVersion

Downloaded from Helda, University of Helsinki institutional repository.

This is an electronic reprint of the original article.

This reprint may differ from the original in pagination and typographic detail.

Please cite the original version. 


\section{PHENOMENOLOGY AND CRISIS TRADITION AND RESPONSIBILITY IN HUSSERL AND HEIDEGGER}

Timo Miettinen

Phenomenology is a tradition of crises. Not only is it a movement that sees itself on the brink of modernity - a turning point in the philosophical tradition of the West-but it is also engaged in a constant struggle over the starting point and target area of its investigations. Phenomenology has not become a fixed system, because it defines itself as a project that cannot become one. As Husserl often remarks, phenomenology — as a philosophical undertaking — is a pursuit of an "absolute foundation," in which "no one line of knowledge, no single truth may be absolutized and isolated." Hence, it is a process of constant critique, repeatedly deciding anew what is primarily evident and meaningful. ${ }^{2}$ Phenomenology is an enterprise of constant separationcrisis.

But as Jacques Derrida claims, the idea of crisis is important for the phenomenological tradition also in another sense. In his work $O f$ Spirit - a book that deals with the concept of Geist (or its absence) in Heidegger's workDerrida claims that it is perhaps the concept of crisis that strikes a gap between Husserl's and Heidegger's thinking. Derrida points out that even though both wish to "awaken Europe and Philosophy to their responsibility," for Heidegger this wake-up call "is not a discourse on crisis." ${ }^{3}$ For both, the idea of crisis signifies a "loss of direction," uncertainty about the ends of the Western philosophy; however, according to Derrida, Heidegger's analyses do remain "radically heterogeneous" with respect to Husserl's Crisis-works. ${ }^{4} \mathrm{He}$ is not talking about a mere difference in the ways approach, but of a more profound separation:

One could even go further: through the appeal

Husserl makes to a transcendental subjectivity

... this discourse on the crisis might constitute

one of the symptoms of the destitution. ${ }^{5}$

What I would like to do in this essay is to ask what is the nature of this separation. My point here is not to argue against Derrida; on the con-

PHILOSOPHY TODAY trary, I want to sketch what could be meant by the "radical heterogeneity" in Husserl and Heidegger's thinking of the crisis.

I will argue that even though Husserl and Heidegger always saw philosophical questioning in relation to the present situation, the problem of crisis was not essentially a question of the present. Their contemporary situations were defined by a strong crisis-consciousness which originated from the discussions of late nineteenth and early twentieth century, but their primary intention was not to offer a form of contemporary criticism. ${ }^{6}$ Instead, the problem of crisis was primarily a question of tradition: what is the nature of our philosophical inheritance and what are our possibilities in making a difference to it.

I will show that even though both Husserl and Heidegger share a certain idea of philosophical-historical teleology that constitutes the unity of our philosophical tradition, what separates them is the willingness and unwillingness to accept this tradition as something inescapable. For Husserl, a responsible renewal of the tradition can help us to overcome the crisis, whereas for Heidegger, tradition is essentially something that cannot be corrected or renewed-but thought. Nevertheless, I will show that Heidegger's position does not lead to a lack of philosophical responsibility, but to its radical reinterpretation.

$$
* * * * *
$$

In Husserl's philosophical work, the idea of crisis appears in several forms: as the crisis of philosophy, as the crisis of science (and especially of the human sciences), as the crisis of reason or rationality, and finally, as an all-encompassing crisis of culture and humanity. Even though the word "crisis" does not appear in Husserl's vocabulary until the 1930s, many commentators - such as Tom Rockmore and Philip J. Buckley-have stressed its implicit role in his early philosophy and thus have ar-

SPEP SUPPLEMENT 2009 
gued for the continuity and unity of Husserl's philosophical project. ${ }^{7}$ In this respect, the word "crisis" merely gathers together the issues that Husserl had worked with in his earlier philosophy: most importantly, the criticism of psychologism, historicism, and naturalism. However, alongside the internal motivation of crisis, we must also pay attention to the external influences. As Husserl noted in his Vienna lecture from 1935, he always saw himself primarily as a "reactionary [to the crisis]" - even though as "far more radical" than his contemporaries. He never wanted to escalate this popular debate but to "root out the popular misunderstandings," take up the challenge that the ongoing crisis-talk had set forth.

One way of capturing the guiding idea of Husserl's early critical reflections is to say that they were a response to an all-encompassing "crisis" of reason or rationality. This unwanted condition can be understood roughly in two ways. First, as a consequence of physicalist and naturalist approaches, our scientific rationality is defined by what Husserl calls "false objectivism": the absolutization of nature or natural-scientific abstractions. In their progress, modern natural sciences rely on a certain omission that concerns their foundations; by operating with scientific abstractions such as "atom" or "synapse," they tend to dismiss the process of meaning-formation upon which they rely. In the words of late Husserl, the natural sciences "forget" the concrete lifeworld experience that forms their origin. Conversely, the second sense of the crisis could be described as "false subjectivism," for in Husserl's view, a considerable part of modern philosophy was in the process of abandoning the whole idea of science as a rational pursuit of necessary and all-embracing truths-this for the sake of subjective preferences. Philosophy and science were succumbing to an unfounded relativism, for example, to the historicist idea that there are no truths that would transcend their respective cultural frameworks, and would thus be valid in every possible condition. ${ }^{10}$

This does not mean, however, that the rise of these misguided "forms of rationality" would have been only an inner problem of philosophy. Already in his essay "Philosophy as Rigorous Science" from 1911, Husserl was convinced that naturalism does not represent a problem only for the scientific enterprise, but that it is "a growing danger for our culture," threat for the life-form that Husserl calls European. This claim becomes understandable in relation to Husserl's definition of Europe. For Husserl, Europe was never in the first place a specific continent, a group of people or a title for a set of shared values, habits, and customs, but what he called a "spiritual form" (geistige Gestalt $),{ }^{12}$ defined by the rigorous and critical task (Aufgabe) that Greek philosophy had set forth. For Husserl, this task was based essentially and only on the idea that all life must be led by reason - that whatever we believe or do, and however we decide to arrange our communal life, we have to have specific grounds for our beliefs and actions. ${ }^{13}$ These grounds are nothing external to us but they lie at the very heart of our subjectivity: the truthfulness of our beliefs and the rightness of our deeds are always given to us at a certain level of adequacy, and our task is to judge and act to the best of our knowledge and capabilities. ${ }^{14}$ It is not the nature of our judgments or actions, but the idea of self-responsible justification that makes them rational. ${ }^{15}$

However, as human beings, we are never completely transparent to ourselves. We tend to develop beliefs, habits, and customs without justifying them rationally: some people smoke without having the faintest idea of why they do so, while others have devoted their whole lives to creating material prosperity without ever considering what good it does. Obviously all this is quite natural. It is however as natural to find oneself in a situation where the groundlessness of one's beliefs and habits starts to reveal itself. This can happen in the form of a pang of guilty conscience or even as a deep personal or existential crisis in which all of our valuations begin to appear unfounded, that is, without intuitive content. Thus to protect against the total loss of value of our life, we must become reflective of ourselves. We must fight against the "natural" forgetfulness to which we tend to succumb; in Husserl's terms, we must adopt the position of constant critique that enables and motivates the process of $r e$ newal (Erneuerung).

With the concept of renewal-which Husserl named as the "chief theme of all ethics" 16 - he means simply the possibility to resist the "loss of intuition" that has its origin in

PHENOMENOLOGY AND CRISIS 
our subjectivity, but that takes place on different levels of meaning-constitution: personal life, religion, politics, science, and so on. With the process of renewal, we have a possibility to regain the lost intuitive content of our insights: for instance, we can reduce the amount of air travel we engage in once we have learned of its harmful consequences to the environment, or we can even give up our profession for the sake of a more justifiable vocation. With this reflective potential of ours, we also have a way of reestablishing the evidence of our "higher order" insights such as scientific beliefs or political practices. This is what being rational means for Husserl: the ability to distance oneself from oneself, to take an active stance towards one's judgments, practices, habits, and value-statements. ${ }^{17}$ Hence, renewal is substantially an active procedure that contends with the essential passivity in us.

The real danger of positivist and naturalist movements was that they were an attack against this idea of self-responsibility. One of the most obvious examples of this was the rise of behaviorist psychology which, to use John B. Watson's expression, recognized no essential difference between "a man and a brute", ${ }^{18}$ the same could have been said of B. F. Skinner's radical determinism which, for instance, proclaimed freedom to be merely an illusion. These stances were dangerous for the simple reason that they were an attack against what Husserl calls the "autonomy of the spiritual"; 19 they were undermining the possibility of voluntaristic behaviour and active renewal. Descartes and the rationalism of the Enlightenment still had faith in the traditional idea of man as rational animal, that is, an essentially self-responsible being, but for the philosophy of the nineteenth century this fundamental "faith in man's freedom" was starting to collapse. ${ }^{20}$ Naturalism and behaviorism claimed that our conscious life is not the true ground of our actions, but that we are merely victims of circumstances: whether these are biochemical processes, neurophysical mechanisms, or some kind of herd instincts. This radical naïveté which not only crosses the limits of reason, but willingly turns against the very idea of rationality, is what constitutes the true crisis.

It is exactly this line of thought that reaches its fulfilment in Husserl's later works on crisis.

\section{PHILOSOPHY TODAY}

Already in the beginning of the 1920s, Husserl had criticized Oswald Spengler's idea on the decline (Untergang) of the West saying it derived from a "passive understanding" of culture. ${ }^{21}$ In Husserl's view, Spengler's ideas were depriving the European culture of its most essential feature — self-responsibility - the ability to strive for infinite goals and to determine its course actively. For the ideas of rationality and responsibility do not concern only individual persons but also communities, nations, and cultures in general; through critique and constant self-renewal, communities-like individuals - have a possibility to adopt a form of self-regulation ("the habitus of critique"22) whereby their traditionally inherited values, practices, customs, and habits are constantly set into re-evaluation. This was actually the culmination of Husserl's late thought: he aimed to show how the highest form of self-responsibility and renewal is not to be found in the finite life of an individual but in the collective responsibility of the whole of humanity. ${ }^{23}$

Thus, according to Husserl, the whole debate on crisis was defined by an insurmountable passivity whereby the crisis was seen as an inevitable consequence-even as a punishment for the European culture. This passivity was something that he wanted to overcome:

\footnotetext{
The "crisis of European existence," which manifests itself in countless symptoms of a corrupted life, is no obscure fate, no impenetrable destiny. Instead, it becomes manifestly understandable against the background of the philosophically discoverable teleology of European history.... [It can] end in only one of two ways: in the ruin of a Europe alienated from its rational sense of life, fallen into barbarian hatred of spirit; or in the rebirth of Europe from the spirit of philosophy, through the heroism of reason that will definitively overcome naturalism. ${ }^{24}$
}

In this respect, the prolific use of the word "crisis" in Husserl's later works can be seen, not only descriptions of an empirical situation, but also as an expression of the active role of philosophy in regard to its tradition. Because even though we have not chosen our historical situation, we are still responsible for the pre-conceptions and prejudices that it contains. Our task is to make comprehensible the historical constitution process of our inherited tradi-

SPEP SUPPLEMENT 2009 
tion-the teleology of history-and to preserve its essential openness: the goals of history are never something completely predetermined but always open to reinstitution. Hence, by invoking the original Greek connotations of "resolution" and "division," Husserl articulated not only the problem but also the solution: our tradition is always something that we have to bring into a crisis, something to which we have to "make a difference." ${ }^{25}$ However, this decision does not lead us outside the tradition, but to the responsible renewal of the original idea of critical philosophy.

\section{$* * * * *$}

What about Heidegger? The starting point of this essay was a passage from Derrida in which he claimed that Heidegger's philosophy was not "on crisis" - at least not in the Husserlian sense of the word. This claim may sound somewhat surprising, if we look at the passages from Introduction to Metaphysics that Derrida is talking about. ${ }^{26}$ Because what Heidegger recognizes there as the source of the crisis of modernity - which he defines as the disempowering (Entmachtung) of the spiritis exactly the inability to question grounds: the unwillingness to seek a rigorous founding of science. What is more, according to Heidegger this crisis stems from Europe itself. It is not the case that Europe was about to lose its originality owing to Asian or other influences, rather the crisis is one of European rationality itself. And like Husserl, Heidegger wants to awaken Europe to realize this crisis-situation. The only possibility for the salvation of Europe (what Heidegger calls "the great decision") ${ }^{27}$ lies in "repeating and retrieving the onset (Anfang) of our historical spiritual existence," 28 that is, the beginning of Western metaphysics. So the question is, is this not precisely what Husserl is trying to do?

To understand and explicate the fundamental difference between Heidegger and Husserl's approaches to the crisis, I will take a leading clue from one of Heidegger's lecture series from the 1930s, Basic Questions of Philosophy (Grundfragen der Philosophie, WS 1937/38). In this lecture series, Heidegger introduces the concept of crisis in relation to what he names as two possible relations to his- tory: one, that he calls historical consideration (historische Betrachtung), and another, that he calls historical reflection (geschichtliche Besinnung). ${ }^{29}$ Whereas historical consideration is interested in facts, states of affairs, and the causal relations between them, historical reflection is directed toward what Heidegger calls the "basic experience" (Grunderfahrung) behind them. For example, Galilean physics is not separated from Aristotelian physics merely by its "method" or "results," but by its different understanding or explication of its basic categories such as space, movement, rest, and so on. ${ }^{30}$ Therefore, historical consideration does not treat history as a constant progress but as what Heidegger calls the "transition of the same" (Verwandlung des Selben): as different answers to the basic metaphysical definitions of what is taken as real, meaningful, and evident. It is namely this idea of crisis as a metaphysical event that Heidegger wants to invoke:

The crisis ... does not stem from 1933 or 1918, not even from the reviled 19th century, but from the beginning of the modern age, which was not a mistake but a destiny and will be overcome only as such. ${ }^{31}$

In the light of this short passage, we can see that there are at least two features that demonstrate the gap between Heidegger and Husserl's analyses.

The first one concerns the crisis as a particularly modern event. As we saw, for Husserl the crisis was manifested most clearly in the positivist, naturalist, and objectivist tendencies of the late nineteenth and early twentieth centuries. However, according to Heidegger's historical reflection, the reason for this crisis was farther reaching. The roots of philosophical objectivism are not to be located in the nineteenth century, but at the "beginning of the modern age," that is, in the rationalism of the sixteenth century that posited the human being as a subject that is the fundamentum absolutum inconcussum, the absolute ground of all meaningfulness. ${ }^{32}$ This birth of modern subjectivism was the starting point for the treatment of all reality as objectivity - as human representation-including human rationality itself.

PHENOMENOLOGY AND CRISIS 
But once subjectivity is viewed as the foundation of all meaningfulness, what happens to its counterpart? What happens to the dimension that transcends this subjectivity - a dimension that could oblige human being and give it meaning? It becomes nothing. Could the crisis, then, be described as the unfolding of nihilism? According to Heidegger, this is at least how Nietzsche saw the matter. For Nietzsche, the history of Western philosophy was internally directed toward its fulfilment, "European nihilism," which for him meant the annihilation or devaluation of all "higher" truths and values. ${ }^{33}$ This development had its origin in Greek philosophy and its Christian reinterpretation in that both neglected the apparent "lived world" for the sake of the eternal and supersensual. According to Nietzsche, this "true world"-originally manifested in Platonist ideas and in the form of Christian God_could no longer maintain its credibility but was to be overcome by a radical subjectivism that could no longer be obliged to accept an authority beyond itself but that set itself its own truths and values. Thus for Nietzsche, "European nihilism" also contained within itself a positive connotation that called for the "revaluation of all values," a way out of purely negative beliefs ("We do not believe in God," etc.). This, of course, was the goal of Nietzsche's Übermensch: the overcoming of modern nihilism through the absolute and totally self-sufficient "will to power."

Heidegger credited Nietzsche with being the first to recognize nihilism, not just as a contemporary moral-ethical phenomenon, but as a development that defines the whole of Western philosophy. ${ }^{34}$ Through this step, Nietzsche pushed the whole problem of crisis into the domain of metaphysics and thus opened up a space for true historical reflection. However, according to Heidegger even Nietzsche was unable to get to grips with the most intimate crisis-the most original decision (Entscheidung) - that defines the whole Occidental tradition. For Heidegger, even Nietzsche could not confront the essence of nihilism as the question of being and its relation to nothingness: Why does being equal presence? Why does "nothing" - that which is absentcount for nothing? According to Heidegger, this "forgetting" was characteristic not only to modern philosophy but to the whole of West-

PHILOSOPHY TODAY ern metaphysics, beginning from Parmenides, Plato, and Aristotle - a metaphysics that had ultimately understood the measure of all reality in terms of absolute and constant presence, and respectively, thinking (noein) in terms of direct and immediate givenness of this presence. ${ }^{35}$ As Heidegger claimed, Nietzsche interpreted this ground not in terms of absolute transcendence - not as a transcendent "idea" or God-but as absolute subjectivity, which is the self-sufficient foundation of all meaningful reality. What modern subjectivism had neglected, along with its Greek ancestors, was precisely the absential dimension that constitutes all givenness-the most fundamental decision between beings-as-present and that dimension (being) which grounds this presence.

We are not, however, interested in describing the character of nihilism in its totalitythis is far too big of a topic_-but in its meaning with regard to the problem of crisis. The second question that arises from the previously quoted passage concerns the possibility of philosophical thinking with regard to the crisis. For if we follow Heidegger by saying that the crisis "was not a mistake but a destiny," does this conception leave any room for a responsible attitude to the crisis?

Certainly, Heidegger's late thinking is quite often seen as being defined by an attitude according to which there is nothing that philosophy can do to make things better; that whatever kind of devastation or deprivation we face, the only possible course of action is to indulge oneself in the tranquillity of Gelassenheit or in a waiting for a future God. This "disinterested" attitude is sometimes viewed as the opposite of Husserl's ideas of philosophy's responsibility and active resistance: whereas Husserl wanted to solve the crisis of mankind by pushing Europe closer to its roots, Heidegger was quite satisfied with just reflecting upon it. ${ }^{36}$

This does not mean, however, that philosophy could do nothing. For these notions of "passive resistance" were not used to describe an indifference toward responsibility for the world but the peculiar possibilities of philosophy with regard to the tradition. For if the most original crisis of thinking consists of the decision (Gr. krinein) between beings-as-present and its Parmenidean antipode, non-being, then the task of thinking cannot consist in the over- 
coming of this pres-absential interplay, but of its unfolding or re-opening. ${ }^{37}$ To put it differently, the most fundamental decision of thinking is not a matter of activity or passivity but of remembering or retrieving (wiederholen). As Heidegger remarked in a discussion of Ernst Jünger's Über die Linie, "with regard to the essence of nihilism, there is no prospect or can be no meaningful claim of healing." ${ }^{38}$ The most intimate possibility of crisis that lies in the nature of humanity cannot be overcome in its essence, for it is the foundation upon which all meaningfulness rests. It is our destiny; not in the sense of historical predestination but in the sense of unavoidable starting point for the constitution of sense.

Thus for Heidegger the real danger was not nihilism itself but its absolutization: "The spiritual decline of the earth has progressed so far that people are in danger of losing their last spiritual strength, the strength that makes it possible even to see the decline." ${ }^{39}$ The destructive force of modern nihilism lies in its tendency to avoid all originary questioning by annihilating everything that transcends pure human subjectivity, everything that could be experienced as something that gives meaning. As for Nietzsche's Übermensch, for the modern man there are only subjective needs and preferences - "brute animality"-but really nothing that could overcome these needs and preferences. Thus, what Heidegger means by the task of thinking in these "times of need," can not be a mere activity of the subject but something more like a willingness for preparation that could help us overcome forgetfulness and confront the crisis in its essence. ${ }^{40}$ As Heidegger later adjusted his views, it is actually highly questionable if there can be such a project as overcoming (Überwindung) nihilism (which was essentially the same thing as the crisis) but only a possibility of surmounting (Verwindung) it, recovering from it, getting through it. ${ }^{41}$

$$
* * * * *
$$

To return to Derrida's original claim about the "radical heterogeneity" of Husserl and Heidegger's relation to the crisis, both philosophers saw the crisis as a situation that concerned the essence of humanity and laid claim to preserve something essential in our human existence. For both, the crisis points toward a definite resolution or decision with regard to the tradition from which it arises. However, in relation to the possibilities and responsibilities of philosophy, a radical difference can be found. For Husserl, the crisis was to be overcome by a responsible renewal of the idea of rational humanity-established with the beginning of Greek philosophy-whereas for Heidegger, a mere renewal of this first beginning was not enough. According to Heidegger, Greek philosophy was already nihilistic in the sense that by grounding itself on the idea of stable and constant presence, it counted the absential dimension that founds this presence for nothing. This essence of nihilism must be opened up again so that it can be experienced as the dimension that lays claim on human being. This is what Derrida means when he says that Heidegger might have viewed Husserl as a "symptom of the crisis." Husserl still tried to find a way out of the crisis by returning to the idea of active subjectivity as the ultimate ground from which all responsibility emerges. Whereas for Heidegger, all responsibility rests on nothing other than our ability to respond: in our capability to confront the dimension which gives meaning.

\section{ENDNOTES}

1. Husserl, Die Krisis der europäischen Menschentum und die Philosophie, HuaVI, 339.

2. This interest toward openings is apparent in Husserl's philosophical motto: "Philosoph, ewiger Anfänger!" See Max Müller, Erinnerung, in: Edmund Husserl und die phänomenologische Bewegung. Zeugnisse in Text und Bild, ed. Hans
Rainer Sepp (Freiburg: Karl Alber Verlag, 1988), 31. Hannah Arendt has pointed out a similar vein in Heidegger's thinking, one that-according to Arendt-"acts in a peculiarly destructive or critical way toward its own results." Hannah Arendt, "Martin Heidegger at Eighty," in Heidegger and Modern Philosophy: Critical Essays, ed. Michael

PHENOMENOLOGY AND CRISIS 
Murray (New Haven: Yale University Press, 1978), 297.

3. Jacques Derrida, Of Spirit (Chicago: University of Chicago Press, 1991), 60-61; De l'espirit (Paris: Galilée, 1987), 94-96.

4. Ibid., 60-61/94-96.

5. “On pourrait même aller plus loin: par l'appel que fait Husserl à une subjectivité transcendantale ... . ce discours sur la crise constituerait justement l'un des symptômes de la destitution" (ibid., 61/ 96).

6. For an extensive account on the modern notion of crisis, see Reinhart Koselleck, Kritik und Krise: Eine Studie zur Pathogenese der bürgerlichen Welt (Freiburg: Alber, 1959).

7. See Tom Rockmore, "The Concept of Crisis and the Unity of Husserl's Position," Man and World 17 (1984): 245-59; Philip J. Buckley, Husserl, Heidegger and the Crisis of Philosophical Responsibility (Dordrecht: Kluwer 1992).

8. Husserl, Die Krisis, 337.

9. Ibid., 317.

10. According to Husserl, both senses rely upon a similar structure of false absolutisation: whereas "the natural scientist sees everything as nature," claims Husserl, "the humanistic scientist sees everything as spirit, as historical creation.” Husserl, Philosophie als strenge Wissenschaft, Hua XXV, 8.

11. Ibid..

12. Husserl, Krisis, 319.

13. Edmund Husserl, Vorträge und Aufsätze (1922-1937), Hua XXVII, 30.

14. One of the key components of Husserl's valuetheory is the concept of the "apprehension of value" (Wertnehmung), which-analogously to "sensual" perception (Wahrnehmung) - is defined in terms of givenness and intuitive fulfilment. Husserl, Vorlesungen über Ethik und Wertlehre (1908-1914), Hua XXVIII, 340-43.

15. Of the idea of responsibility (Verantwortlichkeit) as an epistemological and ethical concept, see especially Edmund Husserl, Erste Philosophie. Zweiter Teil, Hua VIII, 197-98. Cf. Husserl, Cartesianische Meditationen, Hua I, 44; Vorträge und Aufsätze, 169.

16. Vorträge und Aufsätze, 20.

17. Ibid., 23-26.

18. See John B. Watson, "Psychology as the Behaviorist Views it," Psychological Review 20 (1913): 158-77.

19. Husserl, Krisis, 345.

20. Ibid., 11.

\section{PHILOSOPHY TODAY}

\section{4}

21. Vorträge und Aufsätze, 4.

22. Ibid., 64.

23. This ultimate motivation is discussed in Crisis $\$ 7$, and it is shown even more clearly by Fink's outline for the continuation of the work itself (HuaVI, Beilage XXIX). The fifth and final part, to which the whole project of Crisis would have culminated, was titled simply as "The Indispensable Task of Philosophy: Humanity's Self-Responsibility" ("Die unverlierbare Aufgabe der Philosophie: Die Selbstverantwortung des Menschentums," HuaVI, 516). Cf. Husserl's Briefwechsel IV, 224.

24. "Did 'Krise des europäischen Daseins' ist kein dunkles Schicksal, kein undurchdringliches Verhängnis, sondern wird verständlich und durchschaubar auf dem Hintergrund der philosophisch aufdeckbaren Teleologie der europäischen Geschichte. . . . Die Krise des europäischen Daseins hat nur zwei Auswege: Den Untergang Europas in der Entfremdung gegen seinen eigenen rationalen Lebenssinn, den Verfall in Geistfeindschaft und Barbarei, oder die Wiedergeburt Europas aus dem Geiste der Philosophie durch einen den Naturalismus endgültig überwindenen Heroismus der Vernunft" (Krisis, 347-48).

25. At the end of the Vienna lecture, Husserl uses the phrase "we good Europeans" to describe this idea of self-responsibility. By doing this, Husserl actually makes an interesting allusion to Nietzsche, for whom "a good European" means someone who is capable of bearing responsibility for the demise of Christian morality. See Ralf Witzler, Europa in Denken Nietzsches (Würzburg: Königshausen and Neumann, 2001), 198-200.

26. Martin Heidgger, Einführung in die Metaphysik, GA 40, 35-36.

27. Ibid., 29.

28. Ibid., 42.

29. Martin Heidegger, Grundfragen der Philosophie, GA 45, 32-37.

30. Ibid., 52-53.

31. "Aber die Krisis . . stammt nicht von 1933 und nicht von 1918 und nicht einmal aus dem verlästerten 19. Jahrhundert, sondern aus dem Beginn der Neuzeit, der nicht ein Fehler, sondern ein Schicksal war und nur durch ein solches überwunden wird" (ibid., 53-54).

32. Heidegger, Nietzsche: Der europäische Nihilismus, GA 6.2, 124-30.

33. Friedrich Nietzsche, Gesamt.-A VIII/2, ed. C. Colli and M. Montinari, 11[108], 293.

34. Heidegger, Nietzsche, 24.

SPEP SUPPLEMENT 2009 
35. See especially Heidegger's interpretation of Parmenides's fragment DK 28 B 3 ("to gar auto noein estin te kai einai") in Einführung in die Metaphysik, 150-53. See also Heidegger, Nietzsche, 245-54.

36. As Richard Wolin argues: "If the early Heidegger attempted to rally Dasein to 'decisiveness' (Entschlossenheit), the thought of the later Heidegger appears at times to be a summary justification of human passivity and inaction (Gelassenheit).... Thus in the later Heidegger... the powers of human reason and will are correspondingly devaluated." The Politics of Being (New York: Columbia University Press, 1990), 147. See also Alan Megill, Prophets of Extremity (Berkeley: University of California Press, 1985), 180; Stephen Schloesser, “'Only a God Can Save Us': Disabling the Rational Subject in
Heidegger's Reactionary Modernism," The Heythrop Journal 36 (1995): 190-201.

37. The notion of pres-absence has been introduced by Thomas Sheehan, "On the Way to Ereignis: Heidegger's Interpretation of Physis," in Hugh J. Silverman, John Sallis, Thomas M. Seebohm, eds., Continental Philosophy in America (Pittsburgh: Duquesne University Press, 1983), 131-64.

38. Heidegger, "Über die Linie," Wegmarken (Frankfurt-am-Main: Klostermann, 1976), 216.

39. Heidgger, Einführung in die Metaphysik, 29

40. Following Hölderlin, Heidegger calls this wilful attitude that of the "humble" (Geringe). Heidegger, Hölderlins Erde und Himmel, GA 4, 175.

41. See Heidegger's Festschrift on Ernst Jünger's sixtieth birthday, published as a part of Heidegger's Wegmarken with the title "Zur Seinsfrage" (GA 9, 385-462).

University of Helsinki, Finland 00014 